\author{
Roman Budzinowski, ${ }^{1}$ Pawel Czechowski ${ }^{2}$ Matgorzata \\ Korzycka, ${ }^{3}$ Aleksander Lichorowicz, ${ }^{4}$ Staniseaw Prutis ${ }^{5}$
}

\title{
O Profesorze Andrzeju Stelmachowskim jako prawniku
}

W związku z siódmą rocznicą śmierci Profesora Andrzeja Stelmachowskiego, wybitnego prawnika i nauczyciela akademickiego, w dniu 8 kwietnia 2016 roku na Wydziale Prawa Uniwersytetu w Białymstoku, miało miejsce sympozjum naukowe na temat: „Przemiany własności rolniczej w III Rzeczypospolitej Polskiej”. Na kanwie dyskusji merytorycznej, dominowały wszakże wspomnienia poświęcone naszemu Mistrzowi i Jego roli w płaszczyźnie tworzenia, stosowania i nauczania różnych dziedzin prawa. W ramach uroczystości zrealizowano również uchwałę Rady Wydziału Prawa UwB o nadaniu imienia Profesora Andrzeja Stelmachowskiego sali wykładowej nr 313, położonej w budynku Wydziału Prawa, w której Profesor prowadził swoje wykłady. W spotkaniu uczestniczyli reprezentanci wszystkich akademickich ośrodków, katedr i zakładów, prawa rolnego i żywnościowego, a także Rodzina Profesora - Jego syn Stanisław i wnuczka Joanna.

Swoiste ramy organizujące dyskusję i wspomnienia stanowiły wypowiedzi wskazanych wyżej Współautorów, którzy starali się zaprezentować działalność Profesora, Jego dorobek i osiągnięcia, z różnych punktów widzenia.

Profesor Roman Budzinowski wypowiedź swoją opatrzył tytułem: ,Jeszcze o Profesorze Andrzeju Stelmachowskim" podkreślając, iż formacja naukowa Profesora Andrzeja Stelmachowskiego jako agrarysty, Jego wkład w rozwój prawa rolnego, były już przedmiotem odrębnego opracowania. ${ }^{6}$ Dotyczyło ono w szczególności kształtowania się tej formacji i wkładu w rozwój nauki prawa rolnego, a także cech warsztatu naukowego i postawy badawczej oraz przesłań płynących z Jego dokonań. Ograniczenie rozważań tylko do dorobku w zakresie nauki prawa rolnego

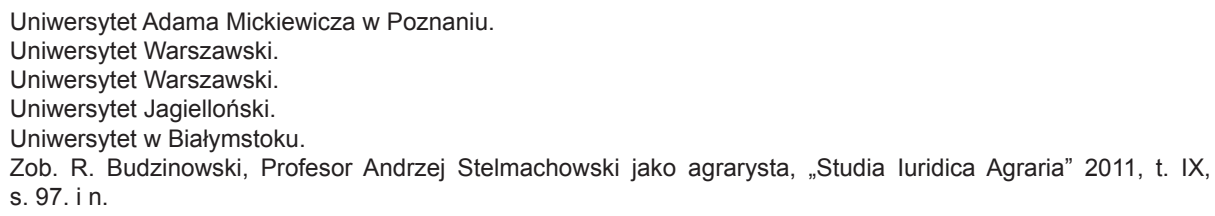


nie oddawało wprawdzie bogactwa osiągnięć, skoro Profesor z sukcesem zajmował się wieloma dziedzinami prawa, ale było zabiegiem usprawiedliwionym z racji przeznaczenia publikacji, adresowanej właśnie do osób zajmujących się wyłącznie, czy przede wszystkim, agrarystyką. Nie można wszakże powiedzieć, że na wiele poruszonych już kwestii nie da się spojrzeć z innego punktu widzenia, czy po prostu wskazać na te aspekty dokonań, które nie były wcześniej szerzej akcentowane. Dlatego przedmiotem niniejszych refleksji R. Budzinowskiego jest wkład Profesora A. Stelmachowskiego w ,rozwój ruchu naukowego zwanego prawem rolnym” (wyrażenie z literatury włoskiej), opowiadanie się za potrzebą prowadzenia badań w zakresie teorii tego prawa oraz inicjatywa opracowania i wydania Systemu Prawa Rolnego. Przedstawienie tych aspektów dokonań uzupełnia dokonaną wcześniej charakterystykę Profesora A. Stelmachowskiego jako agrarysty.

W pierwszej kolejności należy zwrócić uwagę na rolę Profesora w rozwoju nauki prawa rolnego. Refleksje Profesora co do wyodrębnienia prawa rolnego zostały sformułowane w drugiej połowie lat sześćdziesiątych XX w., a więc w okresie, w którym - po zaniechaniu forsownej kolektywizacji - nastąpił znaczny rozwój ustawodawstwa dotyczącego rolnictwa. Jego rozbudowa i komplikowanie się wymagało oczywiście pewnej specjalizacji badaczy, a zatem i odrębnych badań. Można z całą pewnością powiedzieć, że ówczesna nauka nie nadążała za kształtowaniem się swoistej legislacji rolnej, a ówczesne koncepcje teoretyczne nie przystawały do rzeczywistości. ${ }^{7}$ Brakowało w szczególności pewnej, w miarę całościowej, refleksji teoretycznej. Dlatego koncepcje Profesora Stelmachowskiego odegrały zasadniczą rolę w rozwoju nauki prawa rolnego, bo legły u podstaw procesu wyodrębniania się tej gałęzi w ramach systemu prawa.

O tym, jak duże miały one znaczenie, świadczy dyskusja zapoczątkowana referatem: Prawo rolne $w$ systemie polskiego prawa wygłoszonym na konferencji w 1968 r., ${ }^{8}$ a kontynuowana w późniejszym czasie. ${ }^{9}$ Koncepcje Profesora, jak i owa dyskusja, legły u podstaw rozwoju ,ruchu naukowego zwanego prawem rolnym" już w nowych warunkach i uprawianego przez kolejne pokolenia badaczy. Nieodparcie nasuwa się tu pewne skojarzenie z rolą, jaką w zakresie rozwoju nauki o tym prawie odegrali profesorowie: G. Bolla i A. Carrozza we Włoszech, J. Megret i J. Hudault we Francji czy K. Kroeschell i W. Winkler w Niemczech. Niewątpliwie, bez takiego wkładu intelektualnego oraz inspiracji rozbudowywane ustawodawstwo rolne pozostawałoby zapewne przez długi czas raczej działem legislacji, a nauka prawa rolnego znajdowałaby się nadal w stadium kształtowania się.

Por. J. Paliwoda, Polskie prawo rolne, „Acta luridica Agraria” 1999, tom I, s. 30.

Opublikowany w: Zagadnienia prawne rolnictwa, (red.) J. Paliwoda, Wrocław - Warszawa - Kraków 1970. Książka ta zawiera materiały $z$ tej konferencji.

Zob. zwłaszcza J. Nadler, Miejsce prawa rolnego w systemie prawa, „Państwo i Prawo” 1973, nr 1, s. 97 i n. oraz J. Paliwoda, Problem usytuowania prawa rolnego w systemie polskiego prawa oraz kodyfikacji prawa rolnego, „Nowe Prawo” 1973, z. 1, s. 53 i n. 
Charakterystyczne dla postawy badawczej Profesora było dostosowywanie ujęć teoretycznych do zmieniającej się legislacji. Profesor był uważnym obserwatorem rozwoju ustawodawstwa rolnego, śledził jego zmiany, zdawał sobie doskonale sprawę z mobilności granic i rozszerzania przedmiotu regulacji prawa rolnego. Dlatego już w swoich pierwszych definicjach tej dziedziny prawa pominął element tzw. socjalistycznej przebudowy rolnictwa. Oznaczało to odejście od definiowania prawa rolnego jako prawa przebudowy ustroju rolnego (w kierunku socjalistycznym), a zatem pozbawiało to prawo cechy tymczasowości. Odstąpił również (w 1980 r.) od odwoływania się do interesu społeczno-gospodarczego, które pełniło rolę weryfikatora, przesądzało o uznaniu jakiejś instytucji za instytucję prawa rolnego.

Jeszcze później Profesor zrezygnował, w definicji prawa rolnego, z określenia roli Państwa w kształtowaniu ustroju rolnego i produkcji rolnej. Wystąpiło ono, co prawda, w podręczniku opublikowanym po 1989 r., ale nie przystawało już do funkcjonowania rolnictwa w ramach gospodarki rynkowej, w której działalność rolniczą prowadzą autonomiczne podmioty. Wreszcie pod koniec lat dziewięćdziesiątych $\mathrm{XX}$ w. przedmiotem prawa rolnego w ujęciu definicyjnym został objęty ustrój rolny, w tym także produkcja rolna i rynek rolny. Oznaczało to wyraźne rozszerzenie zakresu prawa rolnego, które w warunkach gospodarki rynkowej musiało również rozwiązywać problemy związane z funkcjonowaniem rynku rolnego. Ta charakterystyka ujęć definicyjnych odzwierciedla dynamizm i ekspansję regulacji prawnorolnych. Wskazuje też, że koncepcje teoretyczne nie są stałe, dane raz na zawsze.

Profesor, jak już wcześniej wspomniałem, ${ }^{10}$ zdawał sobie sprawę ze zmian dotyczących samego rolnictwa, jego otoczenia, uwarunkowań międzynarodowych, z konieczności dostosowywania regulacji prawnych oraz poszukiwania nowych ujęć teoretycznych. To właśnie wymienione czynniki wymuszają weryfikację dotychczasowych koncepcji doktrynalnych leżących u podstaw wyodrębnienia prawa rolnego. Profesor wręcz zachęcał do podejmowania problematyki teoretycznej prawa rolnego. Autor w sposób przekonujący wykazał konieczność poszukiwania „ogólnych prawidłowości" w tej dziedzinie prawa i to w czasie, gdy wysiłek badawczy cywilistów spoczywał na naukowym opracowywaniu poszczególnych instytucji. Bez wątpienia, potrzeba podejmowania refleksji teoretycznej w prawie rolnym, o tak rozporoszonej i zmiennej regulacji prawnej, w obliczu nowych wyzwań wspólnej polityki rolnej, nie wymaga uzasadnienia. Powinna ona charakteryzować działalność badawczą agrarysty, który przecież nawet analizę poszczególnych instytucji prawnorolnych może i powinien przeprowadzać z szerszej teoretycznej perspektywy.

Profesorowi głęboko na sercu leżało wzmocnienie nauki prawa rolnego, pokazanie jej osiągnięć. Świadczą o tym prace prowadzone w połowie lat osiemdziesiątych nad opracowaniem Systemu Prawa Rolnego. Z inicjatywą wystąpił Profesor

R. Budzinowski, Profesor Andrzej Stelmachowski..., op. cit., s. 102. 
Andrzej Stelmachowski i na Jego wniosek funkcję redaktora tego dzieła powierzono prof. Wiktorowi Pawlakowi z ośrodka poznańskiego. Profesor uważał, że właśnie prof. Pawlak, ze względu na uwarunkowania polityczne, będzie w stanie $\mathrm{z}$ tego zadania się wywiązać, między innymi uzyskać zgodę i finansowanie wydawcy, to jest Państwowego Wydawnictwa Naukowego. Wydawało się wówczas, że nauka prawa rolnego jest wystarczająco silna, by zrealizować to zamierzenie. Zostały opracowane propozycje dotyczące struktury dzieła i poczyniono wstępne ,przymiarki” co do autorów. Niestety, z wielu względów podjęte prace nie wyszły jednak poza sam etap wstępny, przygotowawczy. ${ }^{11}$ Była to, patrząc z dzisiejszej perspektywy, pierwsza próba integracji środowiska naukowego agrarystów. Potrzeba takiej integracji jest kolejnym przesłaniem płynącym z dorobku Profesora Andrzeja Stelmachowskiego.

Kolejna wypowiedź - Profesor Małgorzaty Korzyckiej - koncentrowała się wokół wiodącej dla prawa rolnego teoretycznej koncepcji Profesora. Wypowiedź nosi tytuł: „Koncepcja własności rolniczej Profesora Andrzeja Stelmachowskiego i jej kontynuacja w pracach uczniów."

Koncepcja własności rolniczej, którą Andrzej Stelmachowski przedstawił po raz pierwszy ok. 50 lat temu jest unikatową w doktrynie prawa polskiego, ze względu na połączenie dwóch zakresów:

1) konstrukcji prawnorzeczowej, zawartej w k.c.;

2) praw podmiotowych właścicieli gruntów, wywodzących się z ustaw.

Tego rodzaju podejście zrywało z fikcją abstrakcyjnej kompetencji właściciela, który zgodnie z art. 140 k.c. może (podkreśl. MK), z wyłączeniem innych osób, w granicach określonych przez ustawy i zasady współżycia społecznego korzystać z rzeczy zgodnie ze społeczno-gospodarczym przeznaczeniem swego prawa na rzecz właściciela, który prawo swoje wykonuje, i jest to zachowanie ze wszech miar powszechne. Oryginalność podejścia A. Stelmachowskiego do własności polega na propozycji konstrukcji odmiennej od klasycznego, cywilistycznego modelu własności. ${ }^{12}$

Nie można pominąć elementu ustrojowego tej koncepcji, która nawiązuje do aktywnego, produkującego rolnika. Co prawda, do właścicieli indywidualnych gospodarstw rolnych obowiązująca w PRL Konstytucja odnosiła się w ujęciu klasowym, używając określenia , „chłop”, ${ }^{13}$ niemniej doznawał on ochrony konstytucyjnej.

Zob. R. Budzinowski, Prace przygotowawcze nad Systemem Prawa Rolnego, „Państwo i Prawo” 1986, z. 10. Cywilistyczny model własności jest to, jak wiadomo, model odziedziczony po prawie rzymskim (triada uprawnień właścicielskich), które kładło nacisk na prawo właściciela, absolutne wobec wszystkich innych.

Określenie „rolnik”, odwołujące się do zawodu, po raz pierwszy pojawiło się w PRL-u w ustawie z 1977 r. dotyczącej emerytur dla rolników. 
Koncepcja zaproponowana przez Profesora A. Stelmachowskiego wynika ze skojarzenia oryginalnej konstrukcji prawa własności ze specyficznym przedmiotem tej własności, jakim jest gospodarstwo rolne. Według tej koncepcji własność rolnicza jest kompleksem praw i obowiązków określających sytuację prawną podmiotu - właściciela gospodarstwa rolnego. ${ }^{14}$

Profesor Andrzej Stelmachowski stał zatem na stanowisku, że rozwiązania cywilistyczne, które odnoszą się do rzeczy, nie wystarczają dla określenia sytuacji prawnej zorganizowanej całości, jaką stanowi gospodarstwo rolne. I stąd zaproponował koncepcję własności rolniczej, która odnosi się do gospodarstwa rolnego, jako swoistego mienia.

Profesor Andrzej Stelmachowski rozważał własność w ujęciu konstytucyjnym i dostrzegał niebezpieczeństwo takich ograniczeń, które mogłyby wypaczyć treść prawa własności. Nie mogą one prowadzić do sytuacji, w której prawa właściciela dadzą się sprowadzić do nudum ius (,nagiego prawa"). ${ }^{15}$ Twierdził również, że „najtrudniejszy jest problem ochrony własności rolnej w zakresie tego jej atrybutu, który tradycyjnie określamy mianem korzystania z rzeczy (por. art. 140 k.c.). Chodzi tu bowiem o konglomerat norm prawnych, które regulują inne materie, ale w sposób niekiedy pośredni wpływają na prawo korzystania z rzeczy". ${ }^{16}$

Pracując pod kierunkiem Profesora Andrzeja Stelmachowskiego byliśmy pod wrażeniem nowatorskiego spojrzenia na własność, a własność w rolnictwie w szczególności - odrywającego się od utartych konstrukcji cywilistycznych i zuniformizowanej interpretacji art. 140 k.c. Tworząca się w okresie lat 60. XX w. szkoła prawa rolnego Profesora Stelmachowskiego zaczęła przynosić owoce w postaci prac Jego uczniów, które dotyczyły również problematyki własności w rolnictwie.

Najszerzej własnością zajął się uczeń i pierwszy doktor Profesora Walerian Pańko w monografii: O prawie wtasności i jego wspótczesnych funkcjach, ${ }^{17}$ głęboko osadzonej w funkcjonalnym podejściu do prawa, które charakteryzuje szkołę Profesora Stelmachowskiego. Profesor W. Pańko stwierdził m.in., że „,.../ istotę prawa własności najprościej, ale i najpełniej wyraża idea domniemania kompetencji: domniemania leżącego po stronie właściciela, a odnoszącego się do ogółu zachowań względem określonej rzeczy (dobra). ${ }^{18}$

14 A. Stelmachowski, Wstęp do teorii prawa cywilnego, Warszawa 1969, s. 227.

15 A. Stelmachowski, Modele własności i ich uwarunkowania społeczno-ustrojowe, [w:] System Prawa Prywatnego, t. 3. Prawo rzeczowe, T. Dybowski (red.), Warszawa 2003, s. 139. Ibidem, s. 183.

W. Pańko, O prawie własności i jego współczesnych funkcjach, Katowice 1984.

Ibidem, s. 75 i n. 
Dr Bolesław Banaszkiewicz ${ }^{19}$ wskazywał na ustrojową równoprawność pracy w gospodarstwie indywidualnym z innymi postaciami pracy zawodowej. Przekonywał, że oczywiście równoprawność ta nie może być traktowana mechanicznie, skoro zawód rolnika indywidualnego cechuje powiązanie statusu osoby czerpiącej środki utrzymania z pracy z pozycją właściciela i przedsiębiorcy. ${ }^{20}$

W latach 70. podjęłam w swojej pracy doktorskiej temat ochrony własności rolniczej, który podsunął mi mój Mistrz i promotor - Profesor Andrzej Stelmachowski. Przyjmując jako punkt wyjścia koncepcję własności rolniczej Profesora postawiłam tezę, iż ochronę tego prawa należy dostrzegać przez pryzmat dobra chronionego i interesu, ze względu na który prawo ochrony tej udziela. Założeniem pracy było przedstawienie istoty zagadnienia ochrony w płaszczyźnie konfrontacji różnych dóbr i interesów, które konkurować będą z „dobrem chronionym” w ramach własności rolniczej, tj. produkcją rolniczą. ${ }^{21}$

Szkoła prawa rolnego, stworzona przez Profesora Andrzeja Stelmachowskiego, której centralnym pojęciem jest własność rolnicza i jej ochrona, znajduje licznych kontynuatorów, którzy twórczo i można powiedzieć „,z rozmachem” rozwijają prawo rolne na uniwersytetach w Polsce, w ramach katedr prawa rolnego, noszących różną nazwę na poszczególnych uniwersytetach. ${ }^{22}$

Myśl Profesora Stelmachowskiego w zakresie własności rolniczej przeżywa obecnie pełne urzeczywistnienie, nie tylko w nauce, ale również przy powstawaniu nowych, kompleksowych rozwiązań prawnych dotyczących zarówno właścicieli rolników, jak i całego kompleksu obszarów wiejskich.

Kolejna wypowiedź, wygłoszona przez Profesora Pawła Czechowskiego, była zatytułowana: „Rola profesora Andrzeja Stelmachowskiego w dydaktyce prawa rolnego".

Na metodykę i dydaktykę prawa rolnego prowadzoną przez profesora Andrzeja Stelmachowskiego istotny wpływ wywierała jego osobowość jako uczonego. Profesor Stelmachowski jako uczony charakteryzował się szerokim spektrum zainteresowań, nie tylko nauką prawa, lecz również naukami społecznymi, historycznymi, co znajdowało swoje odbicie zwłaszcza w Jego sposobie pojmowania prawa, które

Uczeń Profesora Stelmachowskiego, w okresie Solidarności doradca strajkujących rolników, wespół z Profesorem A. Stelmachowskim opracował tekst Porozumień Ustrzycko-Rzeszowskich między strajkującymi rolnikami a władzami PRL w $1981 \mathrm{r}$.

B. Banaszkiewicz, Prawne aspekty pracy w indywidualnym gospodarstwie rolnym, Warszawa 1989, s. 38.

M. Korzycka, Ochrona własności rolniczej, Warszawa 1979.

Na Uniwersytecie Warszawskim jest Katedra Prawa Rolnego i Systemu Ochrony Żywności, na Uniwersytecie Jagiellońskim Katedra Prawa Rolnego, na Uniwersytecie Śląskim Katedra Prawa Rolnego i Gospodarki Przestrzennej, na Uniwersytecie w Lublinie Katedra Prawa Rolnego i Gospodarki Gruntami, na Uniwersytecie Poznańskim Katedra Prawa Rolnego, na Uniwersytecie w Białymstoku Zakład Prawa Rolnego w Katedrze Prawa Cywilnego, w Polskiej Akademii Nauk Zakład Prawa Rolnego i Żywnościowego w Instytucie Nauk Prawnych PAN. 
uzewnętrznione były zarówno w formie wykładów uniwersyteckich oraz w publikacjach.

Używając pojęcia sformułowanego przez Leona Petrażyckiego, Jego metodyka wykładów znajdowała swoje odbicie w naukowych procesach intelektualnych odbywających się w psychice tego wybitnego uczonego i stanowiła zewnętrzny objaw myślenia naukowego, badań i przemyśleń systemowych szeregu problemów naukowych. ${ }^{23} \mathrm{~W}$ oparciu o prowadzoną metodologię nauki prawa rolnego uwzględniającą elementy metody dogmatycznej profesor A. Stelmachowski był zwolennikiem funkcjonalnej płaszczyzny badania prawa, polegającej na rzeczywistym badaniu prawa w działaniu. Bliscy mu byli w szczególności przedstawiciele funkcjonalizmu amerykańskiego, którzy uwzględniali również element empiryczny w badaniu prawa. Ten wybitny Uczony nie stronił również od badania prawa w ramach jego gospodarczych funkcji.

Wskazywał niejednokrotnie, że przez cztery podstawowe czynniki ekonomiczne produkcji, takie jak praca, ziemia, kapitał i organizacja można analizować oddziaływanie instrumentów prawnych na cały proces gospodarczy funkcjonujący $\mathrm{w}$ ramach istniejącego ustroju rolnego.

Wokół tak wybitnego Profesora posiadającego wyraźnie zarysowany indywidualny charakter typu myślenia, gromadzili się zarówno studenci, jak również młodsi pracownicy nauki, którzy z zainteresowaniem uczestniczyli w badaniach empirycznych prowadzonych przez Profesora Stelmachowskiego na obszarach wiejskich. Badaniom tym były poświęcone w szczególności takie instytucje, jak: własność rolnicza, dziedziczenie gospodarstw rolnych, przemiany w strukturze własności publicznej, planowaniu przestrzennym, ochronie gruntów rolnych itp. Profesor Stelmachowski zwykł stawiać zawsze pytania, które związane były z podstawowymi zasadami zarówno prawa cywilnego, jak również prawa rolnego, którego był niekwestionowanym współtwórcą. We Wstępie do teorii prawa cywilnego wskazał m.in., że o samodzielności dyscypliny naukowej decydują zasady przewodnie sformułowane przez doktrynę oraz judykaturę. ${ }^{24}$ Dlatego też nie przypadkowo pracował ze swoimi współpracownikami nad sformułowaniem zasad prawa rolnego. ${ }^{25}$

W metodyce pracy ze studentami profesor A. Stelmachowski wprowadził po raz pierwszy na Uniwersytecie Wrocławskim, a następnie Warszawskim ćwiczenia terenowe, w których to studenci w oparciu o przygotowane wcześniej ankie-

23 L. Petrażycki, O roli wykładów uniwersyteckich, [w:] Z zagadnień teorii prawa i teorii nauki Leona Petrażyckiego, K. Opałek (red.), Warszawa 1969, s. 195 i nast.

24 A. Stelmachowski, Wstęp do teorii prawa cywilnego, Warszawa 1969.

25 P. Czechowski, A. Stelmachowski: Zasady prawa rolnego, „Państwo i Prawo” 1979, z. 12, s. 30-38; P. Czechowski, Zasady prawa rolnego - stabilizacja czy ewolucja, „Studia luridica Agraria” 2011, t. IX, s. 107-113; A. Lichorowicz, Pojęcie i przedmiot prawa rolnego. Miejsce prawa rolnego w polskim systemie prawa, [w:] Prawo rolne, A. Stelmachowski (red.), Warszawa 2009, wyd. 5, s. 30-31. 
ty sporządzali prognozy prawne dotyczące rozwoju badanych gospodarstw rolnych w aspekcie obrotu nieruchomościami, czy też prognoz dziedziczenia. Jego asystenci we wszystkich ośrodkach uniwersyteckich, w których wykładał zostali również „zarażeni” metodologią badań empirycznych, na bazie których powstawały kolejne prace naukowe.

Był również prekursorem prowadzenia zajęć dydaktycznych w formie rozwiązywania przez studentów określonych stanów faktycznych - kazusów, które stanowiły bardzo dobrą podstawę dla sprawdzenia wiadomości nabytych przez studentów w procesie dydaktycznym. Dla seminarzystów sprowadzał z zaprzyjaźnionych archiwów sądowych akta spraw sądowych pozbawione dla celów dydaktycznych tekstów wyroków, które to rozstrzygnięcia studenci opracować musieli samodzielnie na podstawie istniejących analizowanych stanów faktycznych i prawnych. Te metody nauczania prawa w ówczesnym państwie socjalistycznym nie do końca spotykały się z akceptacją środowisk akademickich, które były przyzwyczajone do jedynej w tym okresie „słusznej” metody opartej o analizę formalno-dogmatyczną w ramach uprawianej neonormatywistycznej wykładni prawa.

Koncepcja dydaktyczna opracowana przez Profesora Andrzeja Stelmachowskiego znalazła swoje odzwierciedlenie w kolejnych podręcznikach akademickich, które analizowały całość systemu prawa rolnego, a których poszczególne rozdziały stanowiły w istocie odrębne opracowania monograficzne problemów prawnych. ${ }^{26}$ $\mathrm{Z}$ biegiem czasu kolejne wydania podręczników akademickich pod red. Andrzeja Stelmachowskiego, poza kwestiami ustrojowymi i prawnymi zaczęły obejmować również nowe problemy związane z przyszłą rolą Polski w ramach Unii Europejskiej, ${ }^{27}$ a następnie objęły również problemy graniczne prawa rolnego związane m.in. z rozwojem rynków rolnych, obszarów wiejskich, pomocy unijnej dla rolnictwa, ochrony środowiska, prawa leśnego, finansowania rolnictwa, zrzeszeń rolniczych, prawa żywnościowego.

Pod auspicjami Profesora Stelmachowskiego, u szczytu jego działalności naukowej, powstał wspólny podręcznik akademicki dla wszystkich w Polsce ośrodków uniwersyteckich i szkół wyższych z zakresu prawa rolnego, gromadzący samodzielnych i wyróżniających się pomocniczych pracowników nauki, którzy są jego współautorami. ${ }^{28}$ Podręcznik ten znalazł kontynuację w następnych wydaniach prowadzonych przez uczniów i współpracowników Profesora Stelmachowskiego. ${ }^{29}$

J. Selwa, A. Stelmachowski, Prawo rolne, Warszawa 1970; A. Stelmachowski, B. Zdziennicki, Prawo rolne, Warszawa 1987; A. Stelmachowski, B. Zdziennicki, Prawo rolne, Warszawa 1990.

27 P. Czechowski, M. Korzycka-Iwanow, S. Prutis, A. Stelmachowski, Polskie prawo rolne na tle ustawodawstwa Unii Europejskiej, Warszawa 1994 i Warszawa 1997. 
Profesor A. Stelmachowski odegrał istotną rolę w procesie kształtowania dydaktyki prawa rolnego, która powiązana była ściśle z badaniami naukowymi, a naukowe tezy formułowane przez niego wywoływały naukowe ożywienie, które legło u podstaw gromadzenia się wokół jego osoby uczniów, których umiał wciągnąć do uprawiania nauki, dla których stała się ona jednym z ważniejszych zadań życiowych.

Profesor Aleksander Lichorowicz, podkreślając, iż prezentowane wystąpienia bardzo rzetelnie omawiały podstawowe naukowe osiągnięcia i zasługi Prof. A. Stelmachowskiego w dziedzinie prawa cywilnego i rolnego, zwrócił uwagę, że brakowało pośród nich uwag w kwestii bardzo istotnej dla oceny dorobku Prof. Stelmachowskiego, a mianowicie omówienia Jego zasług i osiągnięć w dziedzinie współpracy naukowej z zagranicą. Dlatego też swoją wypowiedź opatrzył tytułem: „Zasługi Prof. A. Stelmachowskiego w ramach współpracy naukowej z zagranicą".

Kilkanaście lat temu na obchodzie jubileuszu Prof. Stelmachowskiego powiedziałem, parafrazując znane powiedzenie dotyczące Kazimierza Wielkiego, że Profesor zastał polskie prawo rolne drewniane, a zostawił murowane. I właśnie zasługi i osiągnięcia prof. Stelmachowskiego we współpracy z zagranicą stanowią jeden z kluczowych elementów tej przemiany.

Żeby to zrozumieć konieczne jest zdać sobie sprawę z sytuacji, w jakiej znajdowała się nauka polska w PRL lat sześćdziesiątych. Byliśmy praktycznie pozbawieni kontaktów z zachodnio-europejską literaturą i czasopismami prawniczymi, nie mówiąc już o kontaktach osobistych z naszymi europejskimi odpowiednikami np. katedra, w której pracowałem miała prawo zamówić w ciągu roku 2 książki z Europy Zachodniej, na które trzeba było czekać około 2 lat. Stąd nasza wiedza o prawie i doktrynie europejskiej kończyła się często na 1939 r. Bardziej dostępna literatura radziecka, zarówno cywilistyczna, jak i agrarystyczna, jeśli nawet pominąć jej poziom naukowy, była zupełnie niekompatybilna zarówno z polskim obrotem cywilistycznym, jak i ustrojem rolnym. W tej sytuacji prowadzenie w Polsce badań prawno-porównawczych dotyczących romańskiej, germańskiej czy anglosaskiej rodziny prawa było więcej niż utrudnione.

Prof. A. Stelmachowski był, co wiem z rozmowy, jaką prowadziłem z nim w 1967 r. po moim doktoracie, w pełni świadom istniejącej sytuacji i jej szkodliwości dla rozwoju nauki polskiej. Stąd korzystając z pewnego rozluźnienia w kontaktach z Zachodem, jakie nastąpiło w epoce gierkowskiej Prof. Stelmachowski wiele swej energii i kontaktów osobistych poświęcił nawiązaniu współpracy z ośrodkami badawczymi prawa rolnego w Europie Zachodniej.

Działalność tę prowadził nie szczędząc wysiłków i poświęceń nie tylko naukowych, lecz również osobistych. Zawsze będę pamiętać opowieść Profesora, jak chcąc nawiązać pierwszy kontakt z Instytutem Prawa Rolnego we Florencji (IDA- 
IC) musiał spędzić jedną noc na ławce w parku koło siedziby Instytutu czekając na spotkanie z prof. E. Romagnoli. Środki, jakimi dysponował, nie pozwalały bowiem na sfinansowanie najskromniejszego choćby noclegu. Byłoby dobrze, by młodzi współcześni naukowcy korzystający ze szczodrych stypendiów i grantów zechcieli o tym pamiętać.

Swój plan nawiązania kontaktów naukowych z doktryną prawa rolnego w Europie Zachodniej przygotował Profesor bardzo taktycznie i racjonalnie. Rozpoczął od ośrodka włoskiego. Działający tam Instytut Prawa Rolnego (IDAIC) był w owym czasie, pod kierownictwem prof. E. Romagnoli i prof. A. Carrozzy wiodącym prym europejskim centrum doktryny prawa rolnego. Włoskie ustawodawstwo rolne było też wówczas najlepiej rozwinięte w Europie. W późniejszych latach kontakty te „,rozciągnął” Profesor na ośrodek w Ferrarze kierowany przez Prof. L. Costato.

W dalszym etapie nawiązał Prof. Stelmachowski kontakty z bardzo silnym ośrodkiem francuskim, gdzie prym wówczas wodził prof. J. Megret kierujący Academie de l'Agriculture de France. Później kontakty te rozszerzyły się na prestiżowy Uniwersytet Paris I (Pantheon - Sorbonne), gdzie Prof. J. Hudault przejął naukowe „,prowadzenie” po Prof. Megret.

Równocześnie nawiązał Prof. Stelmachowski kontakt z praktycznie jednym, ale za to najbogatszym i najlepiej wyposażonym ośrodkiem niemieckim, którym w owym czasie kierował Prof. K. Kroeschell, zaś spiritus movens był doktor, a później Prof. W. Winkler.

Te nawiązane na przełomie lat 60/70 ubiegłego wieku kontakty kontynuował i rozwijał w coraz szerszym zakresie Prof. A. Stelmachowski przez wiele dziesięcioleci. Trudno na tym miejscu prześledzić wszystkie ich etapy i poszczególne, konkretne osiągnięcia. Zaowocowały one licznymi kontaktami osobistymi, udziałami w wielu konferencjach, stypendiami dla wielu pracowników naukowych, a w końcu na bardzo prestiżowych doktoratach honoris causa Uniwersytetu Paris I (PantheonSorbonne) oraz Uniwersytetu w Ferrarze.

Z aktualnej perspektywy czasu, należało by wskazać na kilka najważniejszych aspektów osiągnięć i sukcesów działalności Profesora A. Stelmachowskiego w ramach naukowych kontaktów z zagranicą:

1) Po pierwsze, należy wymienić pozytywne aspekty nawiązanych kontaktów w sferze legislacyjnej. Niech jako przykład najwcześniejszy służy chociażby wprowadzenie do kodeksu cywilnego, z inicjatywy Profesora, instytucji ustawowego prawa pierwokupu dzierżawcy gruntów rolnych (wprowadzenie art. 695 § 2 k.c. nowelą z 26 października 1971 r.) - rozwiązanie na owe czasy bardzo odważne, a oparte na odpowiednich rozwiązaniach włoskich $\mathrm{i}$ francuskich. Inny, jeszcze istotniejszy, przykład to opracowanie w połowie 
lat 70. XX w., pod kierownictwem Prof. Stelmachowskiego, projektu polskiego kodeksu prawa rolnego bardzo inspirowanego, oczywiście mutatis mutandis, francuskim Code Rural. Projekt ten, obecnie zupełnie zapomniany, był już gotów do rozpoczęcia ścieżki legislacyjnej. Jednakże po interwencji ambasady radzieckiej i wietnamskiej (sic!) został odłożony ad acta jako petryfikujący sektor indywidualny w polskim rolnictwie kosztem sektora uspołecznionego.

2) Aspekt organizacyjny - To niewątpliwie dzięki inicjatywie, staraniom i autorytetowi Prof. A. Stelmachowskiego Polska stała się członkiem Europejskiego Komitetu Prawa Rolnego (CEDR), początkowo członkiem stowarzyszonym, a później rzeczywistym. Fakt, że Polska jako pierwsza z krajów postkomunistycznych zorganizowała seminarium CEDR w Warszawie i Krakowie jest niewątpliwie zasługą Prof. A. Stelmachowskiego, który zabezpieczył stronę finansową seminarium.

3) Aspekt dydaktyczny - Dzięki kontaktom nawiązanym przez Prof. Stelmachowskiego z instytucjami naukowymi Europy Zachodniej młodsza kadra polskich agrarystów mogła, praktycznie w komplecie, odbywać staże zagraniczne w najlepszych europejskich ośrodkach prawa rolnego, a w szczególności we Florencji, Rzymie, Ferrarze, Paryżu, Gottingen, Bordeaux, Nantes etc. Pamiętajmy, że co teraz jest regułą było wtedy trudnym do osiągnięcia sukcesem.

4) Nie można wreszcie zapominać o politycznym aspekcie zagranicznych kontaktów naukowych Prof. A. Stelmachowskiego. Zwłaszcza w początkach lat 90 . XX w. swoje pobyty zagraniczne, udział w konferencjach międzynarodowych wykorzystywał Prof. A. Stelmachowski, czego byłem świadkiem, do kontaktów z elitami politycznymi goszczących go krajów tłumacząc i przybliżając program nowych, solidarnościowych ekip politycznych, co w tym okresie miało bardzo istotne znaczenie.

Prof. A. Lichorowicz konkluduje: „Fakt, że w chwili obecnej polscy agraryści stanowią jedną z silniejszych, liczących się grup naukowych działających w ramach CEDR, że każdy prezes Polskiego Stowarzyszenia Prawników Agrarystów jest ex lege wiceprezesem CEDR, że polscy naukowcy badania prawno-porównawcze z zakresu prawa rolnego traktują jako rzecz oczywistą ma u swych źródeł i podstaw wysiłek, inicjatywę i inwencję Prof. A. Stelmachowskiego. Warto o tym pamiętać."

Ostatnia wypowiedź wygłoszona przez Profesora Stanisława Prutisa koncentrowała się wokół „Zasług Profesora Andrzeja Stelmachowskiego w rozwoju doktryny prawa cywilnego (prawa prywatnego sensu stricto)".

Charakteryzując twórczość i dorobek Profesora A. Stelmachowskiego, S. Prutis podkreślił przede wszystkim wszechstronność Jego zainteresowań badawczych, 
obejmujących praktycznie całość systemu prawa prywatnego, a także dyscypliny oparte na konstrukcjach prawa publicznego (prawo gospodarcze, prawo rolne). Profesor „specjalizował się” niejako w badaniu instytucji prawnych usytuowanych „na styku” kilku dyscyplin prawnych. Fundamentem doświadczeń i osiągnięć Profesora są wszakże badania w dziedzinie prawa cywilnego. Przewodnim motywem twórczości cywilistycznej Profesora jest postrzeganie prawa jako instrumentu realizacji celów społecznych i ochrony doniosłych prawnie i moralnie wartości, takich jak sprawiedliwość, czy słuszność. ${ }^{30}$

Podstawowym problemom prawa cywilnego poświęcony jest cykl traktatów Profesora Andrzeja Stelmachowskiego z zakresu teorii tego prawa. Znaczącym wydarzeniem w rozwoju cywilistyki było pierwsze wydanie ,Wstępu do teorii prawa cywilnego" (1969), w którym Autor zawarł refleksje dotyczące tak ważnych kwestii, jak zasady prawa cywilnego, klauzule generalne w kodeksie, źródła prawa cywilnego, czy problematyka podmiotowości w tym prawie. Druga edycja „Wstępu do teorii..." miała miejsce w 1984 r. i przyniosła przewartościowanie wielu ujęć, dokonane pod wpływem świeżych doświadczeń związanych z powstaniem ruchu ,Solidarność" i próbą jego stłumienia w stanie wojennym. Ukoronowaniem cyklu jest dzieło pt.: „Zarys teorii prawa cywilnego” (1998), bogato uwzględniające doświadczenia i dorobek III Rzeczypospolitej w budowaniu demokratycznego państwa prawnego i gospodarki rynkowej. W podsumowaniu pracy Profesor stwierdza, że , szansą i celem prawa cywilnego winno być zbliżanie do siebie ludzi, zwłaszcza tych wszystkich, którym nie jest obojętna sprawa drugiego człowieka...".31 W traktatach Profesor zajął zdecydowane stanowisko, iż prawo cywilne należy wyodrębniać w systemie prawa, w oparciu o kryterium metody regulacji prawnej; cywilną metodę regulacji prawnej charakteryzuje: autonomia woli podmiotów oraz brak bezpośredniego udziału przymusu państwowego w realizacji norm cywilnoprawnych. Obecnie wydaje się to oczywiste, ale pamiętajmy, że Profesor ogłosił to w 1969 roku blisko 50 lat temu, kiedy to, za kryterium podziału systemu prawa na różne gałęzie, powszechnie uznawany był przedmiot regulacji prawnej. Problematyka prawa cywilnego została zaprezentowana w oderwaniu od powszechnie stosowanego ujęcia „,pandektycznego”, bazującego na podziale na część ogólną, prawo rzeczowe, zobowiązania i spadki. Ujęcie proponowane przez Profesora to ujęcie problemowe - metody regulacji prawnej stosunków społecznych, prawo cywilne w systemie prawa, prawo cywilne a układy innych stosunków (ekonomicznych, politycznych), zasady prawa cywilnego, podmiotowość w prawie cywilnym, własność i odpowiedzialność (nazwane „filarami” prawa cywilnego), mechanizmy zawierania i wykonywania umów, a także konstytucyjne oraz pozakonstytucyjne źródła prawa cywilnego. 
Ujęcie teoretyczne okazało się niezwykle przydatne do badań nad prawem prywatnym, albowiem prawo cywilne to prawo prywatne w znaczeniu węższym..$^{32}$ Ponieważ w doktrynie prawnej realnego socjalizmu nie funkcjonowała kategoria prawa prywatnego, znakomici cywiliści uznali, że w socjalistycznym ustroju ,prawo cywilne było ścisłym surogatem prawa prywatnego", ${ }^{33}$ a w kodeksie cywilnym upatrywać należy fundamentu prawa prywatnego. ${ }^{34}$ Dlatego też traktaty Profesora zatytułowane jako „wstęp” czy „zarys” teorii prawa cywilnego uznać należy - zdaniem moim - za traktaty z zakresu teorii prawa prywatnego sensu stricto, ponieważ prezentując pionierskie podejście badawcze, koncepcje A. Stelmachowskiego są adekwatne i w pełni przydatne do konstrukcji i rozwiązań prawa prywatnego.

Szczególne miejsce w zainteresowaniach badawczych Profesora A. Stelmachowskiego zajmuje instytucja prawa własności. W tym zakresie Profesor uczestniczył w opracowaniu fundamentalnych syntez cywilistycznych, czego wyrazem są Jego poglądy na temat instytucji własności prezentowane w Systemie Prawa Prywatnego. W obszernym rozdziale zatytułowanym: „Modele własności i ich uwarunkowania społeczno-ustrojowe" Profesor przedstawia współczesną stratyfikację własności w Polsce, dokonuje rozgraniczenia własności prywatnej i publicznej oraz omawia funkcjonalne zróżnicowanie własności, dające podstawę do wyodrębnienia własności rolniczej. ${ }^{35}$ Mówiąc o własności rolniczej, podkreślić raz jeszcze należy, że koncepcja zaproponowana przez Profesora A. Stelmachowskiego polega na skojarzeniu ogólnej, lecz oryginalnej koncepcji prawa własności (rozumianego jako kompleks praw i obowiązków określających sytuację prawną podmiotu, czyli właściciela), ze specyficznym przedmiotem tej własności, jakim jest gospodarstwo rolne, które nie jest pojedynczą rzeczą, a czynną, zorganizowaną masą majątkową. ${ }^{36}$ Zdaniem Autora koncepcji, swoisty charakter gospodarstwa rolnego powoduje, że rozwiązania cywilistyczne, które odnoszą się do rzeczy nie wystarczają do określenia sytuacji prawnej zorganizowanej całości, jaką jest gospodarstwo rolne. I tu przydatna jest koncepcja własności rolniczej. Własność rolnicza uzyskuje swój pełny obraz, gdy weźmiemy pod uwagę nie tylko przepisy kodeksu cywilnego, ale i zespół przepisów różnej rangi kształtujących treść własności i sposób jej wykonywania. Także przepisy prawa publicznego regulujące np. zasady ochrony gruntów rolnych, czy obowiązki w zakresie ochrony środowiska, które wpływają w sposób pośredni na możność korzystania przez rolnika ze swojej własności. Suma tych regulacji określa sytuację prawną rolnika. Warto w tym miejscu wspomnieć konkluzję rozważań A. Stelmachowskiego, na temat prawa własności wypowiedzianą w 2007 roku:

Por. M. Safjan, Prawo cywilne - część ogólna, System Prawa Prywatnego, tom 1, Warszawa 2012, s. 55. S. Włodyka, Problem struktury prawa, „Państwo i Prawo” 1995, z. 4, s. 7.

Por. Z. Radwański, Pojęcie prawa cywilnego (uwagi de lege lata i de lege ferenda), [w:] Polskie prawo prywatne w dobie przemian, Księga Jubileuszowa dedykowana Profesorowi Jerzemu Młynarczykowi, Gdańsk 2005, s. 31. System Prawa Prywatnego, Tom 3, Prawo rzeczowe, E Gniewko (red.), s. 217-336.

Por. S. Prutis, Własność rolnicza, hasło [w:] Prawo rolne i żywnościowe, tom VIII, Wielkiej Encyklopedii Prawa, s. $212-213$. 
Roman Budzinowski, Paweł Czechowski, Małgorzata Korzycka i in.

„Cechą charakterystyczną własności rolniczej jest, że wspomniane obowiązki odnoszą się nie tylko do określonych jednostek (...), ile wobec państwa reprezentującego interes społeczeństwa jako całości. W zamian za należyte wykonanie własności rolniczej właściciel ma prawo liczyć na pomoc (ze strony państwa) przy wykonywaniu swego prawa własności" ${ }^{37}$ Obecnie widać doskonale, jak koncepcja własności rolniczej jest przydatna do wyjaśnienia mechanizmów nakładania na rolników publicznoprawnych obowiązków z zakresu ochrony środowiska. ${ }^{38}$

Konkludując, prof. S. Prutis stwierdzit, że Profesor Andrzej Stelmachowski jest twórcą nowej szkoły naukowej prawa rolnego, albowiem swoim dorobkiem naukowym przygotował podstawy teoretyczne do wyodrębnienia (w płaszczyźnie doktrynalnej i dydaktycznej) prawa rolnego jako odrębnej gałęzi; zaproponował oryginalną metodę badawczą - badanie prawa w procesie jego stosowania, i wokół tych idei zorganizował zespoły badawcze - liczne grono uczniów w ośrodkach wrocławskim, warszawskim i białostockim (Profesor wypromował 23 doktorów nauk prawnych).

W uznaniu zasług dla rozwoju nauki prawa, dla budowy demokratycznego państwa prawnego oraz dla kształtowania kultury prawnej narodu Profesor Andrzej Stelmachowski odznaczony został Krzyżem Wielkim Orderu Odrodzenia Polski, a także - pośmiertnie - Orderem Orła Białego.

We wszystkich dziedzinach swojego zaangażowania, pomimo zmian zachodzących w zewnętrznym otoczeniu, Profesor Andrzej Stelmachowski prezentował zawsze trwały system wartości, wśród których wymienić trzeba: prawość, wierność przekonaniom i odpowiedzialność, troskę o dobro wspólne, solidarność ze słabszym i kierowanie się społeczną nauką Kościoła, co zapewniło Mu niekwestionowany autorytet moralny Człowieka o wielkiej sile charakteru, a jednak wyrozumiałego dla ludzkich słabości.

A. Stelmachowski, Modele własności i ich uwarunkowania społeczno-ustrojowe, [w:] System Prawa Prywatnego, Tom 3, Prawo rzeczowe, T. Dybowski (red.), Warszawa 2007, s. 189. 38 Na ten temat por. S. Prutis, Ochrona środowiska za pomocą instrumentów finansowo-prawnych Wspólnej Polity- 
ABOUT PROFESSOR ANDRZEJ STELMACHOWSKI AS A LAWYER

Keywords: agricultural law, agricultural property, European Committee for Agricultural Law, Polish Association of Lawyers specialized in Agricultural Law

Professor Andrzej Stelmachowski (1925-2009) is an outstanding person, deserving huge appreciation because of his activity in various fields; as a lawyer, a prominent specialist in civil law, commercial law, family law, who played a remarkable role in the development of agricultural law. He is the creator of a new school of Polish agricultural law, as he elaborated by his scientific achievements, a theoretical basis to distinguish (in the area of doctrine and didactics) agricultural law as a separate branch of law; he has proposed an original method of research the study of law in the process of its application, and around these ideas he organized research teams - a large group of students at such universities as: Wroclaw, Warsaw and Bialystok (Professor has promoted $23 \mathrm{PhDs}$ of law). Another merit of Professor Stelmachowski was to determine the object and scope of agricultural law, the fundamental structures of agricultural law (the concept of agricultural property), as well as the legal solutions for protection of individual farming. The recognition and respect for the position of Professor at the international level are demonstrated by His numerous professional contacts and honorary doctorates that he was awarded with. The Professor was the first Polish scholar in the CEDR (the European Committee for Agricultural Law), as well as the first President of the Polish Association of Lawyers specialized in Agricultural Law. The concept of teaching elaborated by Professor A. Stelmachowski was reflected in the subsequent editions of academic books in the field of agricultural law, issued under his scientific edit in the period 1970-2008. In all areas of his involvement, despite changes in the external environment, Professor A. Stelmachowski always presented a permanent system of values, among which we should mention: rightness, fidelity to convictions and responsibility, concern for the common good, solidarity with the weak and being guided by the social doctrine of the Church, all of which gave him an unquestionable moral authority as a Person of great strength of character.

\section{Bibliografia:}

Banaszkiewicz B., Prawne aspekty pracy w indywidualnym gospodarstwie rolnym, Warszawa 1989.

Budzinowski R., Prace przygotowawcze nad Systemem Prawa Rolnego, „Państwo i Prawo” 1986, Z. 10.

Budzinowski R., Profesor Andrzej Stelmachowski jako agrarysta, „Studia Iuridica Agraria” 2011, t. IX.

Czechowski P., Stelmachowski A., Zasady prawa rolnego, „Państwo i Prawo” 1979, z. 12. 
Czechowski P., Zasady prawa rolnego - stabilizacja czy ewolucja, „Studia Iuridica Agraria” 2011, t. IX.

Czechowski P. (red.), Prawo rolne, Warszawa 2011.

Czechowski P., Korzycka-Iwanow M., Prutis S., Stelmachowski A., Polskie prawo rolne na tle ustawodawstwa Unii Europejskiej, Warszawa 1994.

Korzycka M., Ochrona własności rolniczej, Warszawa 1979.

Lichorowicz A., Pojęcie i przedmiot prawa rolnego. Miejsce prawa rolnego w polskim systemie prawa, [w:] Prawo rolne, A. Stelmachowski (red.), Warszawa 2009.

Nadler J., Miejsce prawa rolnego w systemie prawa, „Państwo i Prawo” 1973, nr 1.

Paliwoda J., Problem usytuowania prawa rolnego w systemie polskiego prawa oraz kodyfikacji prawa rolnego, ,Nowe Prawo” 1973, z. 1.

Paliwoda J., Polskie prawo rolne, „Acta Iuridica Agraria” 1999, tom I.

Pańko W., O prawie własności i jego współczesnych funkcjach, Katowice 1984.

Petrażycki L., O roli wykładów uniwersyteckich, [w:] Z zagadnień teorii prawa i teorii nauki Leona Petrażyckiego, K. Opałek (red.) Warszawa 1969.

Radwański Z., Pojęcie prawa cywilnego (uwagi de lege lata i de lege ferenda), [w:] Polskie prawo prywatne w dobie przemian, Księga Jubileuszowa dedykowana Profesorowi Jerzemu Młynarczykowi, Gdańsk 2005.

Prutis S., Wspomnienie o Profesorze Andrzeju Stelmachowskim, „Studia Iuridica Agraria” 2009, t. VII.

Prutis S., Ochrona środowiska za pomocą instrumentów finansowo-prawnych Wspólnej Polityki Rolnej, „Studia Iuridica Agraria” 2015, t. XIII.

Prutis S., Własność rolnicza, [w:] Prawo rolne i żywnościowe, [w:] Wielka Encyklopedia Prawa, t. VIII, Warszawa 2015.

Safjan M., Prawo cywilne - część ogólna, System Prawa Prywatnego, tom 1, Warszawa 2012.

Selwa J., Stelmachowski A., Prawo rolne, Warszawa 1970.

Stelmachowski A., Wstęp do teorii prawa cywilnego, Warszawa 1969.

Stelmachowski A., Prawo rolne w systemie polskiego prawa, [w:] Zagadnienia prawne rolnictwa, J. Paliwoda (red.), Wrocław - Warszawa - Kraków 1970.

Stelmachowski A., Modele własności i ich uwarunkowania społeczno-ustrojowe, [w:] System Prawa Prywatnego, t. 3. Prawo rzeczowe, T. Dybowski (red.), Warszawa 2003.

Stelmachowski A. (red.), Prawo rolne, Warszawa 2003.

Stelmachowski A., Zarys teorii prawa cywilnego, Warszawa 1998.

Stelmachowski A., Zdziennicki B., Prawo rolne, Warszawa 1987.

Stelmachowski A., Zdziennicki B., Prawo rolne, Warszawa 1990.

Włodyka S., Problem struktury prawa, „Państwo i Prawo” 1995, z. 4. 